\title{
Non Traumatic Hip Osteonecrosis Treated By Non Vascularised Bone Graft Versus Core Decompression
}

\author{
*Dhary F. hassan; ** Ghadeer H. Majeed, *Abed Falih Al-Sudani
}

\begin{abstract}
Background: Avascular necrosis (AVN) is defined as cellular death of bone components due to interruption of the blood supply; the bone structures then collapse, resulting in bone destruction, pain, and loss of joint function. AVN is associated with numerous conditions and usually involves the epiphysis of long bones, such as the femoral head. In clinical practice, AVN is most commonly encountered in the hip. Early diagnosis and appropriate intervention can delay the need for joint replacement. However, most patients present late in the disease course. Without treatment, the process is almost always progressive, leading to joint destruction within 5 years. Treatment of a vascular necrosis depends mainly on early diagnosis which mainly based on clinical findings, x-ray finding \& MRI.A variety of non vascularized bone grafting techniques have been proposed with varying degrees of success as treatment alternatives for osteonecrosis of the femoral head. The success of these procedures may be enhanced using ancillary growth and differentiation factors.
\end{abstract}

Objectives: To treat non traumatic hip osteonecrosis by non vascularized bone graft versus core decompression.

Type of the study: A retrospective study.

Methods: We retrospectively reviewed 72 patients (88 hips) with osteonecrosis of the femoral head between May 2009, and March 2014,divided into two groups . Group A include 34 patients (44 hips) with osteonecrosis of the femoral head who had non vascularized bone grafting procedures done for them. Minimum follow-up was 12 months. We compared the outcomes in this cohort to similar hip number
(44 hips) in 40 patients treated with core decompression only (group B). We used Phemister technique to make a window at the posterior aspect of greater trochanter to remove necrotic bone and packed the excavated area with autogenous cancellous bone graft taken from ipsilateral iliac crest or leave it without bone graft (decompression only).

Results: We report the result of treatment for femoral head avascular necrosis depending on Ficat classification stage I, II, \& III. The minimum follow up was 12 months (12m-36m). The success percentage of hips in our cohort of patients with non vascularized bone grafting group A are $86 \%$ (38 of 44 hips), which is higher than group B $63 \%$ (28 of 44 hips) with core decompression alone.

Conclusions: These procedures core decompression and autogenous cancellous bone graft may defer joint arthroplasty in selected patients \& it is more effective than core decompression alone in treating early stages of femoral head osteonecrosis.

Keywords: femoral head, osteonecrosis, core decompression and bone graft

Al-Kindy College Medical Journal 2016: Vol. 12 No.2 Page: 49-55

* Orthopedic surgeon F.I.C.M.S. in Al-KI-Kindy teaching hospital.

${ }^{* *}$ Ass. Prof. Orthopedic surgeon F.I.C.M.S. in Al-Kindy college of medicine.

Received $26^{\text {th }}$ Oct 2015, accepted in final $24^{\text {th }}$ Feb 2016

Corresponding to Dhary F. hassan
$\mathrm{O}$ steonecrosis of the femoral head is a devastating disease that often leads to destruction of the hip and the need for total hip arthroplasty ${ }^{[1]}$. Haenisch (1925) and Frelnd (1926) were among the first to report ischemic necrosis of the femoral head ${ }^{[2,3]}$.

In early stages of the disease, head-preserving treatment modalities such as core decompression, osteotomy, and vascularized or nonvascularized bone grafting are often utilized to defer head-replacing options such as total hip arthroplasty ${ }^{[1,4]}$. The rationale for the use of nonvascularized bone grafting is to remove necrotic bone and replace it with cancellous and cortical autografts that support the subchondral bone and articular cartilage of the femoral head and may stimulate bone formation ${ }^{[5]}$. Three different surgical techniques have been popularized for nonvascularized bone grafting: (1) grafting through a core decompression tract (Phemister technique) [6,7,8,9]; (2) grafting through a window or trapdoor in the articular cartilage ${ }^{[10]}$; and (3) grafting through a window made in the femoral neck or femoral head-neck junction [11]. Each of these techniques has its advantages and its limitations. While earlier studies of non vascularized bone grafting through a core tract or cartilage window reported promising clinical results ${ }^{[6,8,12]}$.

In our study, we used Phemister surgical techniques for core decompression of the femoral head with non vascularized bone grafting through a window made at the base of greater trochanter (Fig. 1) ${ }^{[13]}$. We asked whether this technique effectively and similarly deferred further surgical treatment options when compared to those reported in studies not use bone graft in treatment.

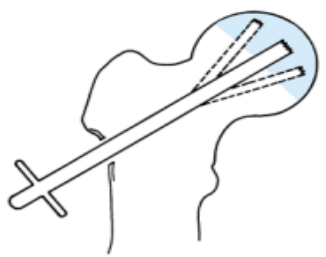


Fig. 1 Technique for performing core decompression. (From Steinberg ME, Brighton CT, Corces A, et al. Osteonecrosis of the Femoral Head. Results of Core Decompression and Grafting. Clin Orthop 1989; 249:199, with permission.) ${ }^{[13]}$

Whereas there are multiple etiologies for the disease, unclear pathogenesis, the pathological condition is remarkably similar in all patients [1]. Irreversible osteonecrosis occur after a minimum of 2 hours of complete ischemia with total anoxia and can be detected by light microscopy after 24 hours of ischemia. Once osteonecrosis develops in the subchondral area of the femoral head, it is thought to follow a defined course ${ }^{[14]}$. The classic radiographic sign of osteonecrosis is increased bone density, (fig. 2). ${ }^{[1]}$

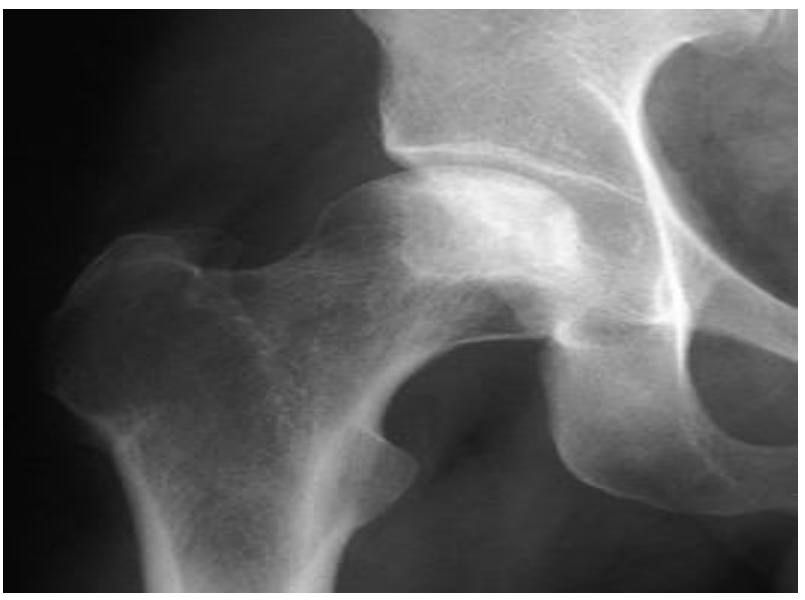

Fig. 2: Stage II osteonecrosis showing areas of sclerosis and radiolucency within the femoral head ${ }^{[13]}$

Plain radiographs alone are often inadequate for the evaluation of the extent of osteonecrosis of the hip because of inter observer variability in grading.

Before the advent of magnetic resonance imaging (MRI), the size of the lesion was estimated with use of outlines of the lesion on anteroposterior and lateral radiograph as described by Kerboul et al ${ }^{[1]}$.

The diagnosis of osteonecrosis of the femoral head does not depend on a single finding. The diagnosis should be considered as established if any of the followings are found: pathognomonic radiographic changes (collapse of femoral head, anterolateral sequestrum or crescent sign $)^{[1]}$, a double line onT2-weighted $\mathrm{MRI}^{[16]}$, increased uptake surrounding a photopenic area (so called cold in-hot) on radionuclide scintinography ${ }^{[1,14]}$ or a positive finding on bone biopsy.

Several staging for femoral head osteonecrosis arise include : Ficat and Arle't ${ }^{[1]}$, Steinberg et al staging system $^{[1,3]}$, The International staging system ${ }^{[1]}$, The Japanese Modification ${ }^{[1]}$,Shimizu classification ${ }^{[1]}$.

We depend on Ficat and Arle't staging system, (Table 1) and is based on standard radiographs.

The system was applied to symptomatic patients. ${ }^{[1]}$
Table 1: Scheme of Ficat classification (1985) ${ }^{[15]}$

\begin{tabular}{|l|l|l|}
\hline Stage & Radiographic signs & Clinical features \\
\hline 0 & $\begin{array}{l}\text { Inconspicious/normal ("silent hip") } \\
\text { findings }\end{array}$ & $\begin{array}{l}\text { Inconspicious findings or } \\
\text { minor changes (slight } \\
\text { patchy osteoporosis, } \\
\text { blurring of trabecular } \\
\text { pattern, subtle loss of } \\
\text { clarity) }\end{array}$ \\
\hline II A & $\begin{array}{l}\text { Diffuse/ focal radiological } \\
\text { changes (osteoporosis, } \\
\text { sclerosis, cysts) }\end{array}$ & + \\
\hline II B & $\begin{array}{l}\text { Subchondral fracture } \\
\text { ("crescent sign") segmental } \\
\text { flattening of femoral head } \\
\text { ("out-of-round appearance") }\end{array}$ & + \\
\hline III & $\begin{array}{l}\text { Broken contour of femoral } \\
\text { head, bone sequestrum, } \\
\text { joint space normal }\end{array}$ & ++ \\
\hline IV & $\begin{array}{l}\text { Flattened contour of } \\
\text { femoral head, decreased } \\
\text { joint space collapse of } \\
\text { femoral head, acetabular } \\
\text { osteoarthritic changes }\end{array}$ & +1 \\
\hline
\end{tabular}

\section{Operative treatment}

Under guidance of image intensification with the patient in supine position. A limited skin incision was made over the lateral aspect of the proximal femur end at the tip of greater trochanter and carried out to a point just $3 \mathrm{~cm}$ below the greater trochanter parallel the femoral shaft, dissection was curried down to the bone after dividing the fascia latae and split the vastus lateralis muscle. A guide wire was placed along the femoral neck into the area of femoral head necrosis using fluoroscopic guidance within approximately $5 \mathrm{~mm}$ of the subchondral plate, a window is opened at the base of greater trochanter by about 1-2 inch and $8-\mathrm{mm}$ bone drill was used to de'bride necrotic bone in the femoral head using the trapdoor as an entrance point. Accidental head penetration with the burr was avoided. The cavity was filled with cancellous bone chips taken from ipsilateral iliac bone crest. The graft was inserted to the hole using a syringe of $2 \mathrm{~mm}$ after cutting its head, the graft should be fill the hole. Finally, vastus muscle and fascia latae were repaired with interrupted sutures. The procedure had a mean operative time of 60-90 minutes. Wound was thoroughly irrigated and closed primarily ${ }^{[2]}$

\section{Materials and Methods}

We retrospectively reviewed 72 patients (88 hips) with osteonecrosis of the femoral head between May 2009, and March 2014 in Al -Kindy teaching hospital ,divided into two groups. Group A include 34 patients (44 hips) with osteonecrosis of the femoral head who had non vascularized bone grafting procedures done for them after core decompression, Group B include 40 patients (44 hips) with osteonecrosis of the femoral head who 
had performed core decompression alone. Indications for the procedure were Ficat and Arlet Stage I, II or III lesions. Minimum follow-up was 12 months (12-32 months). After obtaining institutional review board approval, a prospective database was used to collect relevant surgical, clinical, and radiographic data. We identified the following risk factors and associated conditions with osteonecrosis of the femoral head: corticosteroid usage (defined as a dose greater than $2 \mathrm{~g}$ prednisone or its equivalent per month for 3 months minimum [17], alcohol abuse (defined as alcohol consumption of more than 400 mill per week ${ }^{[18]}$, tobacco abuse (defined as 20 cigarettes or more per day ${ }^{[18]}$. Some patients had more than one associated risk factor. I assessed patients using Hip d'Aubigne system. ${ }^{[19]}$ A score of 15 or more points was considered a successful outcome. Anteroposterior and lateral radiographs were made preoperatively and postoperatively at 6 months \& 1 year. Thereafter, we determined Ficat and Arlet stage [15], combined presence or absence of new bone formation, location of the lesion, and disease progression. In vague cases in which the lesion was not clearly demarcated on plain radiographs, MRI and computed tomography evaluations were used to assist in the evaluation of lesion size.

All patients were maintained at toe-touch weight bearing with two crutches or a walker for 5 to 6 weeks post operatively. For the next 5 to 6 weeks, patients were advanced to approximately $50 \%$ weight bearing using a cane or crutch in the opposite hand. Patients were then advised to start full weight bearing as tolerated at 12 weeks postoperatively. Participation in sports and higher impact loading activities such as running were not recommended for the first 10 months postoperatively.

To assess how the results of the procedures for our cohort compared other core decompressed procedures group $B$ in similarly aged patients at a similar technique $\&$ a same length of follow up. Our result being the use of non vascularised bone graft is better than the decompression only in long life of femoral head to defer arthroplasty.

Results: For both groups the mean age of 32 years (range 18-46 years). For group( $A$ ) there were 18 men $55 \%$ (24 hips), and 16 women $45 \%$ (20 hips), while for group(B) there were22 men $59 \%$ (26 hips) and 18women $41 \%$ ( 18 hips).

Regarding the risk factors we find the steroid abuse in 30 patients (38 hips) $40.6 \%$, alcohol abuse 28 patients (30 hips) $37.8 \%$, tobacco abuse 6 patients ( 8 hips) $8.1 \%$, and 10 patients (12 hips) $13.5 \%$ had no apparent associated risk factors and were deemed idiopathic osteonecrosis. Some patients had more than one associated risk factor.

Of the 44 hips group $(A), 12$ hips were classified as Ficat and Arlet stage I , 18 hips were classified as stage II \& 14hips were classified as stage III preoperatively, while for group(B) ;of the 44 hips, 10 hips were classified as Ficat and Arlet stage I,22 hips were classified as stage II \& 12 hips were classified as stage III preoperatively.

Overall, 38 of the hips survived out of the 44 hips treated $(86 \%)$ had avoided further surgery from group A. When clinical satisfied for all patients in stage I, 16 of the 18 hips with stage II disease did not undergo further surgery. Stage III hips were less successful with 10 of 14 hips surviving. (Table 2). While in group $B, 28$ of the hips survived out of the 44 hips treated (63\%) had avoided further surgery. In stage I, 8 of the 10 hips did not undergo further surgery while in stage II disease 16 of 22 hips did not undergo further surgery. Stage III hips were less successful with 8 of 12 hips surviving. (Table 3).

Table 2. Correlation between Ficat and Arlet stage, and incidence of collapse in group $A$

\begin{tabular}{|l|l|l|l|}
\hline $\begin{array}{l}\text { Ficat and Arlet } \\
\text { Stage }\end{array}$ & $\begin{array}{l}\text { No. of } \\
\text { hip }\end{array}$ & $\begin{array}{l}\text { No. of } \\
\text { collapse }\end{array}$ & $\begin{array}{l}\text { Incidence } \\
\text { of } \\
\text { collapse }\end{array}$ \\
\hline Stage I & 12 & $\begin{array}{l}\text { not } \\
\text { applicable }\end{array}$ & $0 \%$ \\
\hline Stage II & 18 & 2 & $11.1 \%$ \\
\hline Stage III & 14 & 4 & $28.6 \%$ \\
\hline
\end{tabular}

Table 3.Correlation between Ficat and Arlet stage, and incidence of collapse in group $B$

\begin{tabular}{|l|l|l|l|}
\hline Ficat and Arlet Stage & $\begin{array}{l}\text { No. of } \\
\text { hip }\end{array}$ & $\begin{array}{l}\text { No. of } \\
\text { collapse }\end{array}$ & $\begin{array}{l}\text { Incidence } \\
\text { of } \\
\text { collapse }\end{array}$ \\
\hline Stage I & 10 & 2 & $20 \%$ \\
\hline Stage II & 22 & 6 & $27.3 \%$ \\
\hline Stage III & 12 & 8 & $66.7 \%$ \\
\hline
\end{tabular}

There were no perioperative complications documented. There were no medical complications or surgical complication.

The overall early clinical success (fig 3 ) (defined as not later undergoing total hip arthroplasty) rate of $86 \%$ (38 of 44 hips) for group $A$ in which bone graft added, while for group B the early clinical success rate of $63 \%$ (28 of 44 hips) for core decompression alone .table 4

Table 4: clinical \& radiological outcome of core decompression + B.G \& core decompression.

\begin{tabular}{|l|l|l|l|l|l|}
\hline Group & $\begin{array}{l}\text { Sta } \\
\text { ges }\end{array}$ & $\begin{array}{l}\text { N } \\
\text { o. } \\
\text { of } \\
\text { hi } \\
\text { ps }\end{array}$ & $\begin{array}{l}\text { Clinic } \\
\text { al } \\
\text { succe } \\
\text { ss } \\
(\%)\end{array}$ & $\begin{array}{l}\text { Radiologic } \\
\text { al success } \\
(\%)\end{array}$ & $\begin{array}{l}\text { Combine } \\
\text { d } \\
\text { success } \\
(\%)\end{array}$ \\
\hline $\begin{array}{l}\text { Core } \\
\text { decom } \\
\text { pressio } \\
\text { n } \\
+ \text { B.G }\end{array}$ & $\mathrm{I}$ & 12 & $\begin{array}{l}12 \\
(100 \\
\%)\end{array}$ & $12(100 \%)$ & $100 \%$ \\
\cline { 2 - 6 } & & 18 & $\begin{array}{l}16 \\
(88.9 \\
\%)\end{array}$ & $14(77.8 \%)$ & $82 \%$ \\
\cline { 2 - 6 } & & & 12 & $10(71 \%)$ & $78 \%$ \\
\hline
\end{tabular}




\begin{tabular}{|c|c|c|c|c|c|}
\hline & & & $\begin{array}{l}(85.7 \\
\%)\end{array}$ & & \\
\hline & $\begin{array}{l}\text { Tot } \\
\text { al }\end{array}$ & 44 & $\begin{array}{l}40 \\
(90.1 \\
\%)\end{array}$ & $\begin{array}{ll}36 & (81.8 \\
\%) & \end{array}$ & $85 \%$ \\
\hline \multirow{4}{*}{$\begin{array}{l}\text { core } \\
\text { decom } \\
\text { pressio } \\
n\end{array}$} & I & 10 & $\begin{array}{l}8(80 \\
\%)\end{array}$ & $8(80 \%)$ & $80 \%$ \\
\hline & II & 22 & $\begin{array}{l}16 \\
(72.7 \\
\%)\end{array}$ & $\begin{array}{ll}14 & (63.6 \\
\%) & \end{array}$ & $67 \%$ \\
\hline & III & 12 & $\begin{array}{l}4(33 \\
\%)\end{array}$ & $2(16.7 \%)$ & $24 \%$ \\
\hline & $\begin{array}{l}\text { Tot } \\
\text { al }\end{array}$ & 44 & $\begin{array}{l}28 \\
(63.6 \\
\%)\end{array}$ & $\begin{array}{ll}24 & (54.5 \\
\%) & \end{array}$ & $58 \%$ \\
\hline
\end{tabular}

A

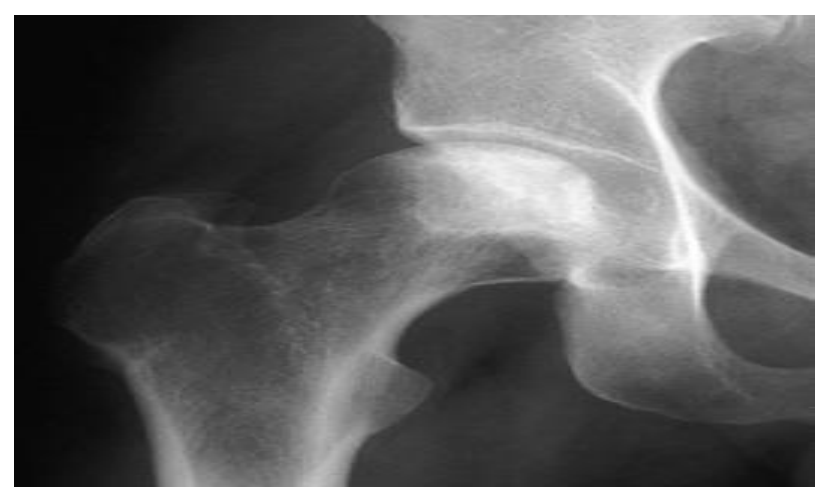

B

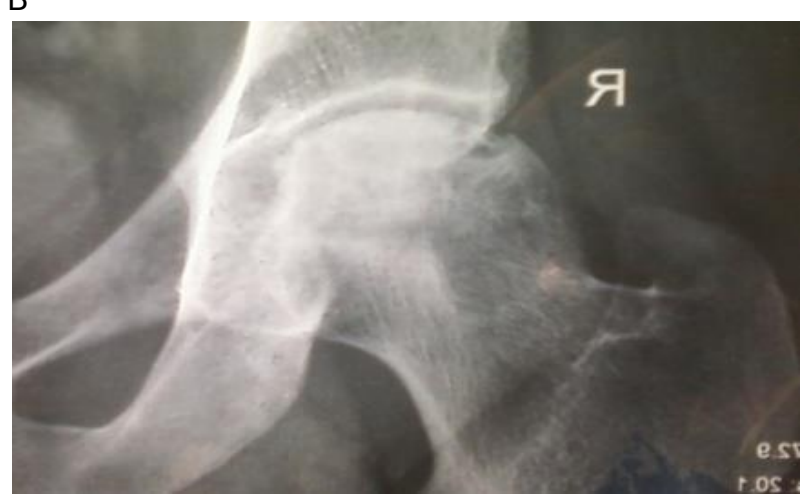

Fig 3: A: stage II AVN

B: result after 1year

Discussion: Nonvascularized bone grafting techniques for the treatment of osteonecrosis of the femoral head were popularized in the $1950 \mathrm{~s}$ and $1960 \mathrm{~s}{ }^{[7,21]}$. The literature reports a wide range of success rates with these techniques and this may be a result of the various surgical techniques and/or reflect the problem of choosing the appropriate treatment modality for the various disease stages. We evaluated our experience with non vascularized bone grafting. The primary questions were whether this technique effectively deferred further surgical treatment when compared to those reported in studies using core decompression treatment only. In addition, we questioned whether the outcomes in this study were comparable to other studies of non vascularized bone grafts. Our study has several shortcomings including the small number of patients and the short-term follow up. Nevertheless, the early results encourage the continued use and further study of this procedure. A larger series with longer follow up will further help assess positive and negative predictors of outcome. Saito et al. ${ }^{[22]}$ reported various treatment modalities for idiopathic necrosis of the femoral head.

The success percentage of hips in our cohort of patients with non vascularized bone grafting group $A$ are $86 \%$ (38 of 44 hips) and were similar to other study at similar mean follow up (range, 12-36 months) (Table 5), while for group B the success percentage of hips are $63 \%$ (28 of 44 hips) for core decompression alone and compared similarly to other decompression procedures performed at similar mean follow up (range, 12-36 months) for comparison (58\%).(Table 6).

Table 5: Literature review of non vascularised bone grafting technique

\begin{tabular}{|c|c|c|c|c|c|}
\hline $\begin{array}{l}\text { Study } \\
\text { (Phemister } \\
\text { technique) }\end{array}$ & $\begin{array}{l}\text { Yea } \\
\text { r }\end{array}$ & $\begin{array}{l}\text { hi } \\
p \\
s\end{array}$ & $\begin{array}{l}\text { Follow } \\
\text { up } \\
\text { Months }\end{array}$ & $\begin{array}{l}\text { Clini } \\
\text { cal } \\
\text { suc } \\
\text { ces } \\
\text { s(\% } \\
\text { ) }\end{array}$ & $\begin{array}{l}\text { Radiol } \\
\text { ogical } \\
\text { Succes } \\
\mathrm{s}(\%)\end{array}$ \\
\hline $\begin{array}{l}\text { Bonfiglio and } \\
\text { Voke }^{[7]}\end{array}$ & $\begin{array}{l}196 \\
8\end{array}$ & $\begin{array}{l}1 \\
1 \\
6\end{array}$ & $\begin{array}{l}\text { 67(24- } \\
204)\end{array}$ & 78 & NA \\
\hline $\begin{array}{l}\text { Boettcher et al } \\
{[6]}\end{array}$ & $\begin{array}{l}197 \\
0 \\
\end{array}$ & $\begin{array}{l}3 \\
8\end{array}$ & $\begin{array}{l}72(24- \\
204) \\
\end{array}$ & 79 & 76 \\
\hline Marcus et al $^{[8]}$ & $\begin{array}{l}197 \\
3\end{array}$ & $\begin{array}{l}1 \\
1\end{array}$ & NA & 90 & 91 \\
\hline $\begin{array}{l}\text { Dunn \&Grow } \\
{[23]}\end{array}$ & $\begin{array}{l}197 \\
7\end{array}$ & $\begin{array}{l}2 \\
3\end{array}$ & $\begin{array}{l}40(27- \\
98)\end{array}$ & 74 & 30 \\
\hline $\begin{array}{l}\text { McBeath } \\
\text { \&Oeljen }{ }^{[24]}\end{array}$ & $\begin{array}{l}197 \\
7\end{array}$ & 6 & NA & 83 & 0 \\
\hline Smith et al ${ }^{[9]}$ & $\begin{array}{l}198 \\
0\end{array}$ & $\begin{array}{l}5 \\
6\end{array}$ & $\begin{array}{l}\text { 144(24- } \\
332)\end{array}$ & 57 & NA \\
\hline $\begin{array}{l}\text { Steinberg et al } \\
\text { [25] }\end{array}$ & $\begin{array}{l}198 \\
4\end{array}$ & $\begin{array}{l}1 \\
9\end{array}$ & $>6$ & 82 & 36 \\
\hline $\begin{array}{l}\text { Buckley et al } \\
\text { [12] }\end{array}$ & $\begin{array}{l}199 \\
1\end{array}$ & $\begin{array}{l}2 \\
0\end{array}$ & $24-228$ & 90 & 90 \\
\hline $\begin{array}{l}\text { Nelson \&Clark } \\
{[26]}\end{array}$ & $\begin{array}{l}199 \\
3 \\
\end{array}$ & $\begin{array}{l}5 \\
2\end{array}$ & $\begin{array}{l}\text { NA(24- } \\
144)\end{array}$ & 77 & 13 \\
\hline $\begin{array}{l}\text { Steinberg et al } \\
\text { [27] }\end{array}$ & $\begin{array}{l}200 \\
1\end{array}$ & $\begin{array}{l}3 \\
1 \\
2\end{array}$ & $\begin{array}{l}63(23- \\
146)\end{array}$ & 64 & 61 \\
\hline Mont et al ${ }^{[T T]}$ & $\begin{array}{l}200 \\
3 \\
\end{array}$ & $\begin{array}{l}2 \\
1 \\
\end{array}$ & $\begin{array}{l}48(36- \\
55)\end{array}$ & 86 & 76 \\
\hline $\begin{array}{l}\text { Plakseychunk } \\
\text { et al }{ }^{[28]}\end{array}$ & $\begin{array}{l}200 \\
3\end{array}$ & $\begin{array}{l}5 \\
0\end{array}$ & $\begin{array}{l}\text { 60(36- } \\
96)\end{array}$ & 36 & 28 \\
\hline Rijnen et al ${ }^{[29]}$ & 200 & 2 & 50(24- & 71 & 57 \\
\hline
\end{tabular}




\begin{tabular}{|c|c|c|c|c|c|}
\hline & 3 & 8 & 119) & & \\
\hline $\begin{array}{l}\text { Lieberman et } \\
\text { al }^{[30]}\end{array}$ & $\begin{array}{l}200 \\
4\end{array}$ & $\begin{array}{l}1 \\
7\end{array}$ & $\begin{array}{l}53(26- \\
94)\end{array}$ & 82 & 82 \\
\hline Kim et al ${ }^{[3 T]}$ & $\begin{array}{l}200 \\
5\end{array}$ & $\begin{array}{l}3 \\
0\end{array}$ & $\begin{array}{l}50(36- \\
67)\end{array}$ & 78 & 80 \\
\hline $\begin{array}{l}\text { Israelite et al } \\
{[32]}\end{array}$ & $\begin{array}{l}200 \\
5\end{array}$ & $\begin{array}{l}2 \\
7 \\
6\end{array}$ & $\begin{array}{l}\text { NA(24- } \\
145)\end{array}$ & 62 & NA \\
\hline Wang et al ${ }^{[33]}$ & $\begin{array}{l}200 \\
5\end{array}$ & $\begin{array}{l}2 \\
8\end{array}$ & $\begin{array}{l}26(24- \\
39)\end{array}$ & 68 & 64 \\
\hline Keizer et al ${ }^{[34]}$ & $\begin{array}{l}200 \\
6\end{array}$ & $\begin{array}{l}8 \\
0\end{array}$ & $\begin{array}{l}84(36- \\
N A)\end{array}$ & 46 & 43 \\
\hline
\end{tabular}

NA: data not available

Table 6. Literature review of decompression treatment outcomes

\begin{tabular}{|l|l|l|l|l|}
\hline Study & Year & $\begin{array}{l}\text { No. of } \\
\text { patients }\end{array}$ & $\begin{array}{l}\text { Follow } \\
\text { up } \\
\text { Months }\end{array}$ & $\begin{array}{l}\text { Successful } \\
\text { rate \% }\end{array}$ \\
\hline $\begin{array}{l}\text { Musso et al. } \\
\text { [35 }\end{array}$ & 1986 & 50 & 30 & 32 \\
\hline $\begin{array}{l}\text { Steinberg et } \\
\text { al. }^{[13]}\end{array}$ & 1989 & 55 & $\begin{array}{l}21 \quad(6- \\
120)\end{array}$ & 16 \\
\hline $\begin{array}{l}\text { Churchill and } \\
\text { Spencer }{ }^{[36]}\end{array}$ & 1991 & 18 & 60 & 50 \\
\hline $\begin{array}{l}\text { Stulberg et al. } \\
\text { [37] }\end{array}$ & 1991 & 22 & 27 & 9 \\
\hline $\begin{array}{l}\text { Robinson and } \\
\text { Springer }{ }^{[38]}\end{array}$ & 1992 & 16 & $\begin{array}{l}39(24- \\
36)\end{array}$ & 56 \\
\hline $\begin{array}{l}\text { Bradway and } \\
\text { Morrey }{ }^{[39]}\end{array}$ & 1993 & 15 & $\begin{array}{l}23(3- \\
66)\end{array}$ & 13 \\
\hline $\begin{array}{l}\text { Jergesen and } \\
\text { Khan }{ }^{[40]}\end{array}$ & 1997 & 19 & $\begin{array}{l}111 \\
(51-81)\end{array}$ & 42 \\
\hline Lai et al. ${ }^{[4]]}$ & 2005 & 25 & 24 & 32 \\
\hline $\begin{array}{l}\text { Hernigou et al } \\
\text { [42] }\end{array}$ & 2006 & 121 & $\begin{array}{l}168 \\
(120- \\
240)\end{array}$ & 25 \\
\hline $\begin{array}{l}\text { Neumayr et al } \\
\text { [43] }\end{array}$ & 2006 & 21 & 63 & 86 \\
\hline $\begin{array}{l}\text { Morse et al. } \\
\text { [44] }\end{array}$ & 2007 & 67 & $\begin{array}{l}23(17- \\
23)\end{array}$ & 70 \\
\hline
\end{tabular}

Despite the limitations of the study, we are encouraged by these early results using cancellous

bone chips as a non vascularized bone grafting technique for the treatment of Stage I, II and III osteonecrosis of the femoral head. The decreased progression of symptoms at a mean of 36 months suggests the natural progression of the disease and subsequent hip arthroplasty surgery has been delayed. This technique is straight forward, has low donor site morbidity, and demonstrates a high degree of efficacy for early Stage and small to medium sized lesions.

\section{Conclusion.}

1 - Core decompression appears to be an acceptable treatment and a reasonable initial surgical intervention for early stages of disease (stage I, IIA sclerotic).

2 - Nonvascularised bone graft is very useful method in treating early stages of femoral head osteonecrosis.

3 - There is no role for core decompression after the disease has progressed to stage IIA (cystic), only for temporal relief of the pain, so another type of treatment should be considered, unless the patient is not candidates for more extensive operative procedures.

4 - Early detection of the disease is the key to get good results.

5 - Patients treated with core decompression should be observed carefully for disease progression. If progression is seen other methods such as bone grafting can be done.

5 - MRI seems to be is the most sensitive imaging for detection of early stages of the disease, and can be used preoperatively to help in predicting the percentage of femoral head collapse post operatively. 6 - Periodic screening to delineate the natural history of asymptomatic hips in all patients with high risk (eg, SLE) to diagnose osteonecrosis as early as possible is mandatory to get good results of treatment.

7 -The procedure provides decompression of the femoral head, removal of necrotic bone, and structural support and scaffolding to allow repair and remodeling of subchondral bone.

8 - The goals in the treatment of osteonecrosis are to relieve pain and preserve the femoral head for as long as possible.

\section{References}

1. Mont, M.A.; and Hungerford, DS.: Non traumatic avascular necrosis of the femoral head. J. Bone and Joint Surg. 77(3): 459-474. 1995.

2. Markel, D.C. at a): Core decompression for osteonecrosis of the femoral head. Cm. Orthop. 323: 226-233, 1996.

3. Wassenaar RP, Verburg $\mathrm{H}$, Taconis WK, van der Eijken JW. Avascular osteonecrosisof the femoral head treated with a vascularized iliac bone graft: preliminary results and follow-up with radiography and MR imaging. Radiographics. 1996;16:585-94.

4. Australian Orthopaedic Association Web site. The National Joint Replacement Registry: Annual Report. Available at: http://www.dmac.adelaide.edu.au/aoanjrr/ documents/aoanjrr_2006_supplementary.pdf. Accessed March 15, 2007.

5. Ganz R, Buchler U. Overview of attempts to revitalize the dead head in aseptic necrosis of the femoral head osteotomy and revascularization. Hip. 1983;296-305.

6. Boettcher WG, Bonfiglio M, Smith K. Non-traumatic necrosis of the femoral head. II. Experiences in treatment. J Bone Joint SurgAm. 1970;52:322-329.

7. Bonfiglio M, Voke EM. Aseptic necrosis of the femoral head and non-union of the femoral neck. Effect of treatment by drilling and bone-grafting (Phemister technique). J Bone Joint Surg Am. 1968;50:48-66. 
8. Marcus ND, Enneking WF, Massam RA. The silent hip in idiopathic aseptic necrosis. Treatment by bonegrafting. J Bone JointSurg Am. 1973;55:1351-1366.

9. Smith KR, Bonfiglio M, Montgomery WJ. Nontraumatic necrosis of the femoral head treated with tibial bone-grafting. A follow-up note. J Bone Joint Surg Am. 1980;62:845-847.

10. Mont MA, Einhorn TA, Sponseller PD, Hungerford DS. The trapdoor procedure using autogenous cortical and cancellous bone grafts for osteonecrosis of the femoral head. J Bone JointSurg Br. 1998;80:56-62.

11. Mont MA, Etienne G, Ragland PS. Outcome of nonvascularized bone grafting for osteonecrosis of the femoral head. Clin OrthopRelat Res. 2003;417:84-92.

12. Buckley PD, Gearen PF, Petty RW. Structural bonegrafting for early atraumatic avascular necrosis of the femoral head. J BoneJoint Surg Am. 1991;73:13571364.

13. Steinberg, M.E. et al: Osteonecrosis of the femoral head. Result of core decompression and grafting with and without electrical stimulation. Clin. Orthop. 249: 199208, 1989

14. Sgano, N. at 1: Contralateral hip in patients with unilateral non traumatic osteortecrosis of femoral head. dim. Orthop. 334: 85-90, 1997.

15. Ficat RP. Idiopathic bone necrosis of the femoral head. Early diagnosis and treatment. J Bone Joint Surg Br. 67 BW: 3-9, 1985.

16. Hayes. C.W.; and Balkisson, A.A.: Magnetic resonance imaging of the musculo skeletal system. Clin. Orthop. 322: 297-309, 1997. 17. Ono K, Tohjima T, Komazawa T. Risk factors of avascular necrosis of the femoral head in patients with systemic lupus erythematosus under high-dose corticosteroid therapy. ClinOrthop Relat Res. 1992;277:89-97.

18. Matsuo K, Hirohata T, Sugioka Y, Ikeda M, Fukuda A. Influence of alcohol intake, cigarette smoking, and occupational status on idiopathic osteonecrosis of the femoral head. Clin Orthop RelatRes. 1988;234:115-123.

19. Harris WH. Traumatic arthritis of the hip after dislocation and acetabular fractures: treatment by mold arthroplasty. An endresult study using a new method of result evaluation. J Bone JointSurg Am. 1969;51:737755.

20. Rosenwasser MP, Michelsen CB, Kiernan HA. Treatment of avascular necrosis of the femoral head with curettage, iliac cacellous bone grafting, and revascularization with gluteus muscle pedicle flap. Orthop Trans. 1983;7:396.

21. Bonfiglio M, Bardenstein MB. Treatment by bonegrafting of aseptic necrosis of the femoral head and nonunion of the femoral neck (Phemister technique). J Bone Joint Surg Am. 1958;40: 1329-1346.

22. Saito S, Ohzono K, Ono K. Joint-preserving operations for idiopathic avascular necrosis of the femoral head. Results of core decompression, grafting and osteotomy. J Bone Joint Surg Br. 1988;70:78-84.
23. Dunn AW, Grow T. Aseptic necrosis of the femoral head. Treatment with bone grafts of doubtful value. Clin Orthop RelatRes. 1977;249-254.

24. McBeath AA, Oeljen CG. Phemister bone graft for osteonecrosis post renal transplant. Clin Orthop Relat Res. 1977:164-168.

25. Steinberg, M.E. at al: Treatment of avascular necrosis of the femoral head by a combination of bone grafting, decompression, and electrical stimulation. Clin. Orthop. 186: 137--153, 1984.

26. Nelson LM, Clark CR. Efficacy of phemister bone grafting in nontraumatic aseptic necrosis of the femoral head. J Arthroplasty. 1993;8:253-258.

27. Steinberg ME, Larcom PG, Strafford B, Hosick WB, Corces A, Bands RE, Hartman KE. Core decompression with bone grafting for osteonecrosis of the femoral head. Clin Orthop Relat Res. 2001;386:71-78.

28. Plakseychuk AY, Kim SY, Park BC, Varitimidis SE, Rubash HE, Sotereanos DG. Vascularized compared with nonvascularized fibular grafting for the treatment of osteonecrosis of the femoral head. J Bone Joint Surg Am. 2003;85:589-596.

29. Rijnen WH, Gardeniers JW, Buma P, Yamano K, Slooff TJ, Schreurs BW. Treatment of femoral head osteonecrosis using bone impaction grafting. Clin Orthop Relat Res. 2003;417:74-83.

30. Lieberman JR, Conduah A, Urist MR. Treatment of osteonecrosis of the femoral head with core decompression and human bone morphogenetic protein. Clin Orthop Relat Res. 2004;429: 139-145.

31. Kim SY, Kim YG, Kim PT, Ihn JC, Cho BC, Koo KH. Vascularized compared with nonvascularized fibular grafts for large osteonecrotic lesions of the femoral head. J Bone Joint Surg Am. 2005;87:2012-2018.

32. Israelite C, Nelson CL, Ziarani CF, Abboud JA, Landa J, Steinberg ME. Bilateral core decompression for osteonecrosis of the femoral head. Clin Orthop Relat Res. 2005;441:285-290.

33. Wang CJ, Wang FS, Huang CC, Yang KD, Weng LH, Huang HY. Treatment for osteonecrosis of the femoral head: comparison of extracorporeal shock waves with core decompression and bone-grafting. J Bone Joint Surg Am. 2005;87:2380-2387.

34. Keizer SB, Kock NB, Dijkstra PD, Taminiau AH, Nelissen RG. Treatment of avascular necrosis of the hip by a non-vascularised cortical graft. J Bone Joint Surg Br. 2006;88:460-466.

35. Musso ES, Mitchell SN, Schink-Ascani M, Bassett CA. Results of conservative management of osteonecrosis of the femoral head. A retrospective review. Clin Orthop Relat Res. 1986;207:209-215

36. Churchill MA, Spencer JD. End-stage avascular necrosis of bone in renal transplant patients. The natural history. J Bone Joint SurgBr. 1991;73:618-620.

37. Stulberg BN, Davis AW, Bauer TW, Levine M, Easley K. Osteonecrosis of the femoral head. A prospective randomized treatment protocol. Clin Orthop Relat Res. 1991;268:140-151. 
38. Robinson Jr. HJ, Springer JA. Success of core decompression in the management of early stages of avascular necrosis: A four year prospective study. Orthop Trans. 1993;16:707.

39. Bradway JK, Morrey BF. The natural history of the silent hip in bilateral atraumatic osteonecrosis. J Arthroplasty. 1993;8:383-387.

40. Jergesen HE, Khan AS. The natural history of untreated asymptomatic hips in patients who have nontraumatic osteonecrosis. J Bone Joint Surg Am. 1997;79:359-363.

41. Lai KA, Shen WJ, Yang CY, Shao CJ, Hsu JT, Lin $\mathrm{RM}$. The use of alendronate to prevent early collapse of the femoral head in patients with nontraumatic osteonecrosis. A randomized clinical study. J Bone Joint Surg Am. 2005;87:2155-2159.81
42. Hernigou P, Habibi A, Bachir D, Galacteros F. The natural history of asymptomatic osteonecrosis of the femoral head in adults with sickle cell disease. J Bone Joint Surg Am. 2006;88:2565-2572.

43. Neumayr LD, Aguilar C, Earles AN, Jergesen HE, Haberkern CM, Kammen BF, Nancarrow PA, Padua E, Milet M, Stulberg BN, Williams RA, Orringer EP, Graber $\mathrm{N}$, Robertson SM, Vichinsky EP. Physical therapy alone compared with core decompression and physical therapy for femoral head osteonecrosis in sickle cell disease. Results of a multicenter study at a mean of three years after treatment. J Bone Joint Surg Am. 2006;88:2573-2582.

44. Morse CG, Mican JM, Jones EC, Joe GO, Rick ME, Formentini $\mathrm{E}$, Kovacs JA. The incidence and natural history of osteonecrosis in HIV-infected adults. Clin Infect Dis. 2007;44:739-748. 